GENERASI EMAS

Jurnal Pendidikan Islam Anak Usia Dini

Volume 1, No. 2, 2018

\title{
ANALISIS KEGIATAN BIMBINGAN BELAJAR PADA ANAK USIA DINI DALAM KREATIVITAS PEMBELAJARAN FINGER PAINTING
} (Melukis Terhadap Peningkatan Motorik Halus)

\author{
Noviea Varahdilah Sandi ${ }^{1}$, Ririn Setyorini ${ }^{2}$ \\ Pendidikan Guru Sekolah Dasar ${ }^{1}$, Pendidikan Bahasa Indonesia ${ }^{2}$ \\ FKIP Universitas Peradaban \\ Email: noviea011@gmail.com, ririnsetyorini91@gmail.com
}

\begin{abstract}
This research analyzes the learning of color game and painting concept by using Finger Painting, this study also analyzes early childhood creativity in playing their imagination. The design of this research is qualitative research and using the descriptive method, which is to study and describe the fine art learning by seeing a child's creativity through their soft motoric skill in learning Finger Painting. The technique of collecting data is done by observation, documentation, and interview. The subject of this research focused on early childhood which follows 'Rumah Pintar' tutoring activity in Bandung district. The result of the research showed that: 1) Children that joint on tutoring activity have enthusiast in learning. 2). When painting, they prefer using their imagination (they don't paint what they look, 3). Children's creativity increases in mixing many kinds of tint. 4). The success of painting creativity achieved, 5). There is an effect of learning finger painting activity to the enhancement of children's soft motoric.
\end{abstract}

Key Words: Creativity, Early Childhood, Finger Painting, Soft Motoric.

\section{PENDAHULUAN}

Kegiatan belajar tidak harus berada di suatu tempat yang berbentuk formal, dengan adanya guru, kepala sekolah, serta murid. Akan tetapi, ada bentuk pembelajaran nonformal yang masih banyak digemari oleh lingkungan setempat yaitu bimbingan belajar, alasan masyarakat memilih anaknya masuk pada kegiatan bimbingan belajar adalah untuk menambah ilmu di luar jam sekolah sehingga tidak harus mendapatkannya di sekolah saja. Kata lain dari bimbingan belajar adalah bimbingan 
GENERASI EMAS

Jurnal Pendidikan Islam Anak Usia Dini

Volume 1, No. 2, 2018

belajar pada umumnya hanya dapat diperbolehkan untuk anak-anak sekolah dasar, sekolah menengah pertama serta sekolah menegah atas, akan tetapi sesuai denga berjalannya waktu saat ini bimbingan belajar sudah mulai berkembang di lingkungan TK atau bahkan PAUD. Tujuan dengan diadakannya bimbingan belajar untuk program anak PAUD serta TK adalah untuk memudahkan anak mendapatkan pembelajaran yang berbeda dengan yang diperoleh selama di sekolah, selain itu pun membantu anak untuk beradaptasi dengan berbagai pembelajaran baru yang lebih menyenangkan serta sesuai dengan usia anak. Kegiatan bimbingan belajar di Rumah Pintar menggunakan teknik belajar dengan bermain, pendidik berharap agar peserta didik tidak mengalamin kejenuhan ketika belajar.

Kegiatan bimbingan belajar yang dilaksanakan untuk kebutuhan anak usia dini sampai anak sekolah dasar, mempunyai tujuan agar, menjadikan anak mudah bergaul, mudah beradaptasi dengan lingkungan baru, mengendalikan anak yang pemarah, serta membantu mengembangkan motorik halus anak. Selain itu bimbingan belajar sering dianggap sebagai jasa penitipan anak, banyak orang tua yang sibuk bekerja sehingga tidak ada banyak waktu untuk mengurus anak, maka dibuka program bimbingan belajar bernama Rumah Pintar, yang dikelola oleh sarjana pendidikan yang masih berperan aktif berprofesi sebagai guru sekolah dasar. Program ini dibentuk hanya untuk anak yang masih berusia di bawah 10 tahun, diantaranya anak-anak PAUD, TK dan SD. Pembelajaran yang diperoleh berbentuk praktik menggunakan teknik bermain, pembelajaran yang diberikan diantaranya: belajar menghitung (matematika), belajar membaca, belajar menulis, mengaji, bernyanyi (seni musik), menari tradisional (seni tari), serta belajar finger painting dan menggambar (seni rupa).

Pendidikan anak usia dini (PAUD) merupakan pendidikan yang paling dasar dibandingkan dengan pendidikan yang lain. Hal ini anak didik dibimbing melalui pembinaan dan pengembangan potensi anak usia di bawah 6 tahun. Dengan hal ini, maka pendidik harus dapat memposisikan pembelajaran yang sangat dasar sesuai dengan kemampuan usia anak PAUD. Untuk itu akan memberikan pembiasaan kepada anak sehingga merangsang pertumbuhan serta perkembangan anak.

Menurut Selia Dwi Kurnia (2015) dalam jurnalnya yang berjudul "Pengaruh Pengembangan Paining dan Keterampilan 
GENERASI EMAS

Jurnal Pendidikan Islam Anak Usia Dini

Volume 1, No. 2, 2018

Motorik Halus terhadap Kreativitas Anak Usia Dini dalam Seni Lukis", memaparkan bahwa Pendidikan Anak Usia Dini (PAUD) pada hakikatnya adalah pendidikan yang diselenggarakan dengan tujuan untuk memfasilitasi pertumbuhan dan perkembangan anak secara menyeluruh atau menekankan pada pengembangan seluruh aspek kepribadian anak. Oleh karena itu, PAUD memberikan kesempatan bagi anak untuk mengembangkan kepribadian dan potensi secara maksimal. Atas dasar ini, lembaga PAUD perlu menyediakan berbagai kegiatan yang dapat mengembangkan berbagai aspek perkembangan seperti kongnitif, bahasa, sosial, emosi, fisik, dan motorik. Terkait perkembangan anak yang masih membutuhkan banyak pendidikan sehingga sesuai dengan usianya anak PAUD diberikan pembelajaran dasar yang tidak sulit untuk dipelajari, dengan memberikan metode belajar sambil bermain akan membantu meningkatkan motorik halus anak sehingga anak akan mudah menyerap berbagai pendidikan yang telah didapatkan.

Pendidik memberikan berbagai pendidikan yang kiranya dapat menyerap pertumbuhan perkembangan anak di usia dini. Menurut Sujiono (2007) memaparkan bahwa, pendidikan anak usia dini adalah suatu upaya pembinaan yang ditunjukkan dari anak sejak lahir sampai dengan usia enam tahun yang diakukan melalui pemberian rangsangan pendidikan untuk membantu pertumbuhan dan perkembangan jasmani dan rohani agar anak memiliki kesiapan dalam memasuki pendidikan lebih lanjut. Rangsangan yang baik akan membantu pertumbuhan anak yang baik, jika sejak usia dini anak diberikan pembelajaran yang bermanfaat maka hasil yang didapat pun sesuai dengan apa yang dipelajarai senjak usia dini. Di usia yang tergolong dini, yaitu 0-8 tahun dikatakan golden age (usia emas), merupakan usia yang paling tepat untuk dibentuk menjadi pribadi yang baik serta tumbuh menjadi anak yang cerdas, berkreativitas, berpotensi serta anak yang produktif.

Hasil dari pengamatan yang telah dilaksanakan pada program Bimbingan belajar yang bertepatan di Rumah Pintar Kabupaten Bandung, ditemukan bahwa masih kurang optimalnya kualitas pembelajaran seni rupa yang disebabkan oleh beberapa faktor diantaranya:

1. Sarana yang tersedia masih kurang

2. Model pembelajaran seni rupa yang diterapkan belum optimal 
3. Masih kurangnya bahan untuk melukis, sehingga peserta didik sering kali mengalami keributan

4. Sering mengalami keborosan dalam penggunaan cat lukis

\section{METODE PENELITIAN}

Penelitian ini dilaksanakan di Rumah Pintar, merupakan tempat bimbingan belajar yang bertempatkan di Kabupaten Bandung Jawa Barat. Peserta didik yang mengikuti kegiatan tersebut masih kurang dari 10 anak, dikarenakan banyak orang tua yang kurang berminat mengajak anaknya mengikuti kegiatan tersebut. Metode yang digunakan merupakan deskritif kualitatif yang bertujuan untuk mendeskripsikan proses pembelajaran Finger Painting (Seni Rupa) terhadap peningkatan motorik halus anak.

Subjek dalam penelitian ini berfokus pada anak usia dini yang terlibat mengikuti kegiatan bimbingan belajar di Rumah Pintar kabupaten Bandung. Teknik pengumpulan data menggunakan teknik triangulasi yaitu observasi, wawancara dan dokumentasi.

\section{HASIL DAN PEMBAHASAN}

\section{a. Kreativitas anak usia dini dalam pembelajaran Finger Painting}

Anak yang memiliki bakat besar mempunyai rasa penasaran ingin tahu serta ingin mencoba hal baru merupakan salah satu anak yang terbilang kreatif. Anak kreatif merupakan anak yang tumbuh dengan mencoba, dengan mencoba anak mendapatkan pengalaman baru yang mendorong pertumbuhan untuk berpikir dan bertindak.

Usia dini merupakan kesempatan emas orang tua serta pendidik untuk mendorong anak menjadi anak yang diharapkan, usia ini merupakan usia anak mudah untuk dituntun serta dibentuk, ada baiknya dalam kegiatan pembelajaran peran orang tua sangatlah diharapkan untuk membantu anak berkembang menjadi anak yang memiliki pribadi baik, mulai dari cara berpikir yang positif, disiplin, menghargai lingkungan, mandiri, memahami ajaran agama yang dianut, serta memiliki sifat dewasa. Kreativitas tumbuh secara alami, adapun bantuan dari lingkungan yang mendorong agar anak pada usia dini dapat tumbuh menjadi anak yang aktif serta produktif.

Munandar (1995) mendefinisikan kreativitas sebagai kemampuan untuk membuat kombinasi baru, asosiasi baru berdasarkan bahan, informasi, data atau 
GENERASI EMAS

Jurnal Pendidikan Islam Anak Usia Dini

Volume 1, No. 2, 2018

elemen-elemen yang sudah ada sebelumnya menjadi hal-hal yang bermakna dan bermanfaat. Terkait uraian tersebut maka dapat dipahami bahwa kreativitas merupakan hal sebagai kemampuan membuat atau menciptakan sesuatu yang baru, sesuatu yang baru tersebut dapat didapatkan dari proses berpikir dan bantuan dari berbagi lingkungan.

Kreativitas anak usia dini diharuskan kreatif, manusia yang kreatif adalah manusia yang memiliki ide serta gagasan baru, dimana ada aktifitas dalam berpikir yang membangun atau positif, dan menciptakan suatu hal yang baru (produktif), diperkuat oleh kutipan dari Suharnan (dalam Nursisto, 1999) menuliskan bahwa terdapat beberapa komponen pokok dalam kreativitas yang dapat dijelaskan sebagai berikut:

a. Aktifitas berpikir

Kreativitas selalu melibatkan proses berpikir di dalam diri seseorang. Aktifitas ini merupakan suatu proses mental yang tidak tampak oleh orang lain, dan hanya dirasakan oleh orang yang bersangkutan. Aktifitas ini bersifat kompleks, karena melibatkan sejumlah kemampuan kognitif seperti persepsi, atensi, ingatan, imajeri, penalaran, imajinasi, pengambilan keputusan, dan pemecahan masalah. b. Menemukan atau menciptakan sesuatu Yang mencakup kemampuan menghubungkan dua gagasan atau lebih yang semula tampak tidak berhubungan, kemampuan mengubah pandangan yang ada dan menggantikannya dengan cara pandang lain yang baru, dan kemampuan menciptakan suatu kombinasi baru berdasarkan konsep-konsep yang telah ada dalam pikiran. Aktifitas menemukan sesuatu berarti melibatkan proses imajinasi yaitu kemampuan memanipulasi sejumlah objek atau situasi di dalam pikiran sebelum sesuatu yang baru diharapkan muncul.

c. Sifat baru atau orisinal

Umumnya kreativitas dilihat dari adanya suatu produk baru. Produk ini biasanya akan dianggap sebagai karya kreativitas bila belum pernah diciptakan sebelumnya, bersifat luar biasa, dan dapat dinikmati oleh masyarakat.

Aktifitas berpikir. Pembelajaran yang melatih anak dalam pembentukan motorik halus diupayakan pendidik mencari pelajaran yang merangsang daya ingat anak untuk dapat berpikir aktif, sehingga anak dapat berkembang sesuai yang diharapkan. Aktifitas berpikir dalam pembelajaran seni 
GENERASI EMAS

Jurnal Pendidikan Islam Anak Usia Dini

Volume 1, No. 2, 2018

rupa yang melatih kepekaan anak salah satunya Finger Painting, dalam pembelajaran ini anak usia dini diberikan pengetahuan terkait beberapa macam warna, dan beberapa warna campuran yang menciptakan warna lain, setelah itu peserta didik memberikan penjelasan terkait empat warna yang akan dicampur dengan beberapa warna lain, dengan diikuti oleh peserta didik, ketika melakukan praktik anak-anak langsung menghafal macam-macam warna serta cara mencampur cat dengan warna lain agar tercipta warna yang diharap, selain itu menurut salah satu peserta didik B mengatakan bahwa warna hijau dapat digunakan untuk membuat daun dan pohon, sedangkan warna coklat dapat digunakan untuk warna lukis pohon dan tanah. Di sini terbukti aktifitas anak sangat terlihat dari daya ingat yang kuat, bermain imajinasi dan pengambilan keputusan. Proses pembelajaran Finger Painting yang melatih kreativitas anak usia dini dalam aktifitas berpikir membuktikan hasil yang baik.

\section{Menemukan Atau Menciptakan}

Sesuatu. Hampir semua pembelajaran pada anak usia dini lebih banyak berbentuk praktik yang sifatnya untuk mempermudah mengembangkan kreativitas anak dalam belajar. Pembelajaran yang monoton bagi anak sangatlah kurang menarik, hal ini akan menjadi salah satu hal yang membosankan dan anak cenderung malas untuk mengikuti kegiatan belajar, salah satu upaya agar peserta tertarik mengikuti kegiatan bimbingan belajar, Rumah Pintar mempunyai ide dalam kegiatan belajar agar anak disuguhkan dengan metode teknik bermain. Dunia anak adalah dunia bermain, dunia bermain adalah dunia anak, jika pembelajaran pada anak usia dini disamakan dengan metode belajar di sekolah dasar bukanlah perkara yang mudah melainkan perkara yang dianggap sulit, karena anak masih senang untuk bermain. Pembelajaran Finger Painting yang dilaksanakan pada kegiatan bimbingan belajar di Rumah Pintar mempunyai tujuan agar peserta didik dapat menciptakan sesuatu yang baru. Setelah mempelajari atau mengenal berbagai macam warna dan mencampurkan warna lain agar tercipta warna yang diinginkan, selanjutnya peserta didik diberikan arahan agar dapat melukis pohon menggunakan warna yang telah diracik. Pendidik memberikan kesempatan anak untuk melakukan belajar melukis menggunakan cat lukis, biasanya anak-anak melukis dengan menggunakan krayon atau pensil warna, dalam kegiatan kali ini anak diperkenalkan dengan cat lukis jari 
yang sudah terjamin kualitas keamanannya untuk anak. Dalam pembelajaran kali ini anak ditugaskan untuk melukis pohon, tanpa ada contoh dari pendidik, pendidik sengaja memberikan teknik ini agar anak memainkan imajinasinya, dengan begini anak akan cenderung untuk mempunyai pilihan dalam berpikir dibanding melihat. Salah satu peserta didik memberikan penjelasan bahwa warna hitam dan coklat dapat digunakan untuk menampilkan warna pada pohon dan akar, sedangkan warna coklat dan hijau dapat digunakan untuk warna tangkai dan daun. Kreativitas pembelajaran yang diharapkan dalam melukis pohon menggunakan jari dan cat, melatih anak untuk dapat berkembang ketika berpikir. Dengan diadakannya teknik bermain sambil belajar ini menunjukan hasil bahwa anak berhasil menemukan serta menciptakan sesuatu yang baru, dalam hal ini anak yang berhasil membuat Finger Painting pohon dengan menggunakan pilihan warna yang tersedia adalah anak yang produktif, karena muncul dari konsep imajinasi, berpikir dan menciptakan suatu hal yang baru.

Sifat baru atau orisinal. Melihat dari kutipan di atas, maka dapat diambil penjelasan bahwa dalam pembelajaran Finger Painting yang dilakukan pada kegiatan Rumah Pintar terlihat anak-anak yang kreatif. Anak yang terbilang masih sangat kecil sudah mempunyai bakat untuk berpikir, berimajinasi serta dapat menciptakan produk atau karya.

Kreativitas dalam pembelajaran Finger Painting pada kegiatan bimbingan belajar di Rumah Pintar memberikan efek yang baik bagi anak, anak lebih senang untuk belajar karena menggunakan teknik bermain, hal ini yang menjadikan anak mempunyai kemampuan untuk berpikir tanpa ada beban. Menurut Mulyadi (2000:30) mengemukakan kreativitas dapat didefinisikan sebagai kemampuan untuk membuat kombinasi baru berdasarkan data, informasi atau unsur-unsur yang ada. Kreativitas juga bisa diartikan sebagai kemampuan yang mencerminkan kelancaran, keluwesan, dan orisinalitas dalam berpikir. Kreativitas berarti pula kemampuan untuk mengembangkan, memperkaya, dan merincikan suatu gagasan. Dalam kreativitas pada pembelajaran Finger Painting, terbukti anak lebih menggunakan imajinasi, berpikir, dan menghasilkan produk atau karya. 


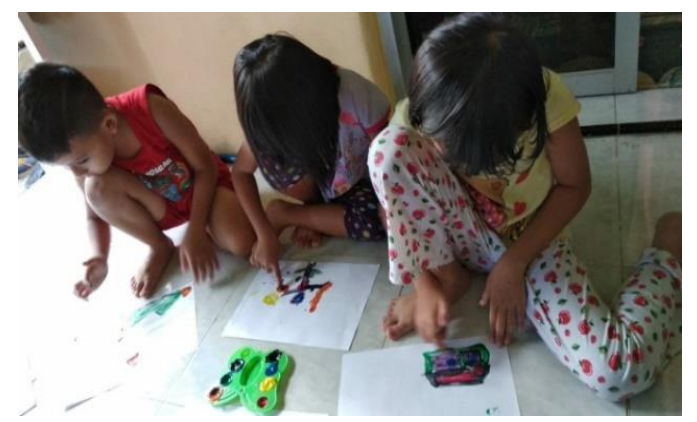

Gambar 1 : Menunjukan anak yang mulai belajar Finger Painting

\section{b. Melukis dalam Perkembangan Motorik Halus Anak}

Melukis diterapkan dalam kegiatan pembelajaran untuk membentuknya motorik halus anak salah satunya dengan melakukan kegiatan pembelajaran Finger Painting yang diterapkan dalam kegiatan bimbingan belajar di Rumah Pintar, membuahkan hasil atau manfaat yang sangat mendukung untuk perkembangan anak di usia yang masih sangat dini. Pada dasarnya, tujuan dari pengembangan motorik halus menurut Yudha M Saputra dan Rudyanto (2005: 115) ada tiga, yaitu:

a. Mampu memfungsikan otot-otot kecil seperti gerakan jari tangan.

b. Mampu mengkoordinasikan kecepatan tangan dan mata.

c. Mampu mengendalikan emosi.

Melihat kutipan yang diambil dari Yudha M Saputra, menegaskan bahwa dengan diadakannya kegiatan belajar melukis dapat melatih otot-otot kecil pada gerakan jari, hal ini akan mempelancar anak dalam belajar menulis, menggambar, melukis dan menggunting, selain itu pun dapat mengkordinasi antara kecepatan tangan dan mata, sehingga akan memudahkan anak untuk menuangkan karyanya dengan apa yang sebelumnya ada di dalam pikiran atau imajinasi, dengan hal ini akan dapat mengendalikan emosi karena anak akan terlebih dahulu berpikir sebelum bertindak.

Perkembangan motorik halus anak dalam melukis, dapat memiliki kelebihan atau manfaat untuk kehidupan sehari-hari, berikut beberapa manfaat dengan diadakanya belajar Finger Painting untuk anak usia dini, menurut Anggraeni Septi diantaranya :

\section{Melatih motorik halus}

Hasil observasi serta beberapa data yang akurat ketika melakukan penelitian, terlihat sangat jelas anak-anak yang sering bermain dengan warna, melukis serta menggambar ketika mereka menulis jarijarinya sudah lentur, walau masih dalam tahap belajar menulis dan hasil tulisan masih kurang dikatakan belum maksimal, akan tetapi anak sudah pandai memainkan jarinya 
untuk memegang serta memainkan pensilnya dengan tenang.

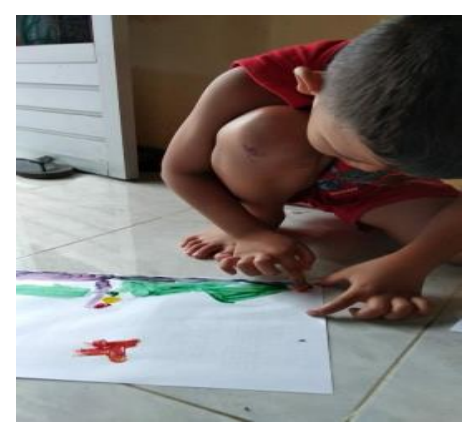

Gambar 2 : Peserta didik yang sedang melatih jarinya untuk bergerak

\section{Mengembangkan koordinasi mata dan tangan}

Mengembangkan koordinasi antara mata dan tangan, anak akan belajar untuk berfokus, melihat apa yang ada di depan mata. Hal ini pun sangat didukung dengan berpikir, karena merupakan salah satu dari kreativitas anak dalam belajar melukis. Seperti yang pernah ditemui ketika observasi di lapangan, salah satu anak mengalami aktifitas belajar melukis dengan tenang, walau pun diajak berbicara ia tetap berfokus menyelesaikan lukisannya karena yang bekerja adalah tangan dan mata, sedangkan mulut dapat digunakan untuk berbicara. Hasil wawancara dengan salah satu peserta didik C menegaskan bahwa, ketika melukis menggunakan pikiran, mata dan tangan harus bersatu agar dapat menghasilkan lukisan yang bagus. Hasil dari wawancara tersebut melihatkan keterlibatan pengembangan koordinasi mata dan tangan harus seimbang.

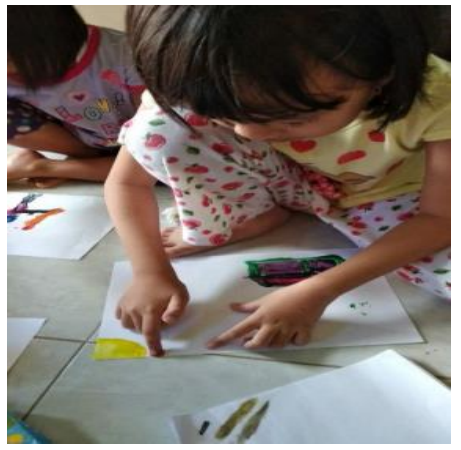

Gambar 3 : Peserta didik sedang mengkoordinasi mata dan tangan

\section{Mengembangkan indra peraba atau sensori}

Pelatihan Finger Painting diharapkan peserta didik dapat menggunakan rabaan hassil karnyanya dengan jari, dengan begini akan terlihat jelas gambar mana yang harus ditipiskan dan ditebalkan dengan cat, dalam teknik ini peserta didik belum dapat menguasai disebabkan masih belum dapat serius ketika belajar.

\section{Mengembangkan kemampuan berbahasa}

Terkait dengan mengembangkan kemampuan bahasa, dari semua anak yang terlibat langsung dalam pelatihan bimbingan belajar di Rumah Pintar banyak anak yang aktif untuk bertanya, berpendapat serta mengeluarkan keluhannya, peserta didik D 
GENERASI EMAS

Jurnal Pendidikan Islam Anak Usia Dini

Volume 1, No. 2, 2018

mengakui bahwa dia sering keliru dalam penyebutan warna cat, sedangkan peserta A lebih banyak mengeluh karena kelelahan, namun siswa $\mathrm{C}$ lebih semangat untuk melukis mulai dari pemebntukan serta pencampuran warna cat, cara melukis dengan cat yang basah serta tangan kotor, dan mengeringkan hasil lukisannya dan teksturnya akan lebih kasar. Anak tidak akan tau basah dan kasar jika ia tidak pernah bersentuhan dengan benda riel.

\section{Membantu anak untuk fokus atau konsentrasi}

Pembelajaran Finger Painting anakanak lebih banyak untuk untuk bermain sambil belajar, banyak anak yang mencoba untuk bertanya serta ingin segera mencoba melukis. Kegiatan ini membantu anak untuk lebih berkonsentrasi dan berfokus, dengan hal ini anak akan terlihat lebih sibuk sehingga sangat antusias untuk segera menyelsaikan karyanya.

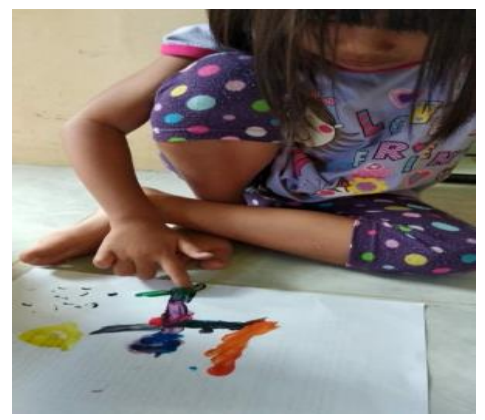

Gambar 4 : Peserta didik sedang fokus dan konsentrasi melukis

\section{Mengenalkan warna}

Awal perkenalan Finger Painting, pendidik memberikan contoh lukisan yang telah selesai dikerjakan, lalu selanjutnya memperkenalkan berbagai macam warna cat yang dapat dicampur dengan warna lain, untuk menghasilkan warna yang diinginkan. Manfaat yang didapat adalah orang tua tidak perlu repot mengenalkan berbagai warna kepada anak, karena anak akan lebih cepat menjawab warna apa yang dilihatnya.

\section{Mengembangkan dan mengenalkan keindahan warna}

Menuangkan berbagai macam warna cat di kertas gambar, anak akan merasa bahagia karena hasil lukis yang ada diimajinasinya dapat diciptakan dalam bentuk karya dengan berbagai warna menarik, begitu pun dengan hasil observassi yang didapatkan, semua anak merasa sangat bahagia melihat karyanya yang telah tercipta di atas kertas.

\section{Mengembangkan imajinasi dan kreativitas}

Dunia bermain adalah dunia anak, sehingga anak serasa berjelajah di dunianya, berkaitan dengan pembelajaran Finger Painting anak sudah mulai belajar untuk berpikir pada arahan yang akan dicapai, 
GENERASI EMAS

Jurnal Pendidikan Islam Anak Usia Dini

Volume 1, No. 2, 2018

ketika melakukan observasi di lapangan serta terjun langsung menyaksikan pembelajaran Finger Painting, terlihat anak-anak sudah dapat berimajinasi, mempunyai bayangan apa yang akan dilukis, hal ini yang menjadikan anak berkreativitas dalam memilih tema, gambar serta warna.

\section{Keberanian}

Keberanian menaklukkan rasa takut kotor, takut salah dan takut menyatukan warna, peserta didik diberikan kebebasan untuk bertanya keluhan apa yang dirasa, dengan mengutarakan perasaannya pendidik akan memberikan arahan sehingga anak tidak ada rasa takut untuk mencoba. Melihat fenomena yang terjadi di Rumah Pintar, sangat terlihat jelas semua peserta didik tidak mengalami rasa takut untuk mencoba melukis menggunakan cat, mereka beranggapan melukis menggunakan jari adalah hal yang baru serta sangat menarik untuk dipelajari.

\section{Percaya diri}

Belajar melukis dengan jari merupakan tahapan awal peserta didik usia dini, untuk mempelajari serta membuat karya. Hampir semua peserta didik mengalami kegembiraan, dengan hasil akhir yang didapat ketika selesai melukis, sehingga timbul percaya diri bahwa hasil yang diperoleh menarik dengan bentuk dan berbagai warna. Terkait dengan hal ini efek yang baik untuk anak-anak adalah dengan merasakan rasa percaya diri yang kuat sehingga anak tidak minder ataupun tidak merasa malu untuk belajar kembali. Ditemukan masih ada beberapa anak yang malu untuk menunjukan hasil karyanya dengan alasan takut menjadi bahan bercanda teman-temannya.

\section{Membantu mengekspresikan emosi}

Belajar Finger Painting pun dapat membantu mengekspresikan emosi, dimana anak dengan mudah mengendalikan emosi marah, dengan belajar melukis jari anak akan merasa terhibur dengan memainkan cat dengan jari-jarinya yang mungil, serta menuangkan perasaannya di atas kertas gambar, sehingga tercipta ekspresi emosi gembira.

Melukis jari dengan mengembangkan motorik halus anak mempunyai banyak manfaat untuk membantu menumbuh kembangkan anak menjadi anak yang kreatif serta produktif, sesuai dengan penemuan yang telah dideskripsikan di atas, maka tidak ada salahnya peserta didik untuk mengikuti kegiatan bimbingan belajar, untuk 
GENERASI EMAS

Jurnal Pendidikan Islam Anak Usia Dini

Volume 1, No. 2, 2018

menambahkan berbagai ilmu serta agar anak dapat melakukan ide kreatifnya pengalaman yang bermanfaat untuk

pertumbuhan anak. Bahwa keterampilan motorik halus anak menggunakan kemampuan tangan, mata, imajinasi dan berpikir, selain itu pun melibatkan dukungan yang positif untuk pertumbuhan anak agar tidak merasa takut dan mempunyai sifat percaya diri yang baik untuk mengembangan kreativitas yang menantang di jenjang pendidikan berikutnya.

\section{c. Peran Finger Painting pada Anak Usia Dini}

Pengembangan kreativitas anak dalam peran pembelajaran seni melukis adalah agar anak lebih banyak berpikir dalam segala hal, dengan berpikir akan menumbuhkan kreativitas yang akan menghasilkan suatu produk atau karya yang baru. Menurut M. Adler mengatakan bahwa seni lukis adalah sesuatu yang memberikan kesenangan. Jenis melukis yang akan dipelajari di Rumah Pintar disesuaikan dengan karakter anak usia dini, melukis yang dipelajari pada anak usia dini adalah memberikan kebebasan anak untuk menentukan sendiri jenis atau tema apa yang menjadi salah satu pilihannya, sehingga dengan begitu pendidik memberikan ruang

yang akan diwujudkan dalam bentuk karya.

Menurut Munandar

(2004:7)

Pendidikan anak usia dini sebagai sumber strategi pembangunan sumber daya manusia haruslah dipandang sebagai titik sentral dan sangat fundamental serta strategis, mengingat usia dini merupakan masa keemasan namun sekaligus periode yang sangat kritis dalam tahap perkembangan manusia. Pertumbuhan dan perkembangan anak pada usia dini, sangat menentukan derajat kualitas manusia pada tahap berikutnya. Kegiatan Finger Painting diberikan untuk meningkatkan kreativitas anak usia dini, kegiatan ini merupakan kegiatan yang membantu anak untuk menggunakan jarinya untuk melukis menggunakan cat khusus, dengan mengeksplor ide serta imajinasinya ke karya yang menarik, hal ini merupakan kegiatan yang berkreativitas untuk tumbuh kembang anak usia dini.

Finger Painting atau lukis jari merupakan kegiatan bermain untuk anak usia dini, dengan melukis anak merasa dapat menuangkan ekspresinya serta dapat menuangkan segala pendapat imajinasinya ke dalam bentuk karya. Menurut Prasetyono (2007:107) menjelaskan bahwa, melukis adalah kegiatan yang sangat menyenangkan 
GENERASI EMAS

Jurnal Pendidikan Islam Anak Usia Dini

Volume 1, No. 2, 2018

bagi anak, dalam kegiatan ini, anak bisa dengan bebas mengekspresikan jiwanya dalam bentuk coretan-coretan yang mungkin bagi orang dewasa tidak mempunyai arti. Tetapi bagi anak, coretan sekecil apapun mewakili imajinasinya yang ditansformasikan ke dalam coretan-coretan yang penuh makna dan arti. Terkait dalam kegiatan tersebut dunia anak tidak dapat dipisahkan dengan dunia bermain, apa yang menjadi salah satu imajinasinya harus dapat disalurkan dalam bentuk karya, bagi anak apa yang telah dikerjakan adalah karya yang bagus dan menarik, dengan hal demikian tanpa disadari anak akan melanjutkan karya berikutnya, dan berusaha untuk mengembangkan imajinasi-imajinasi yang terkonsep dalam pikirannya.

Sesuai dengan hasil wawancara dengan seluruh peserta yang terlibat langsung

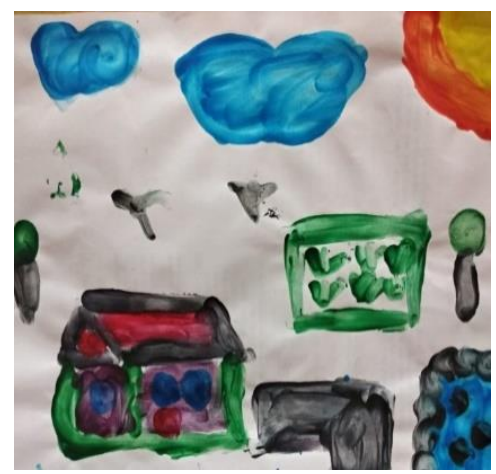

Gambar 5. Karya Siswa A dalam kegiatan bimbingan belajar Finger Painting, dari pernyatakan mereka dapat dideskripskikan bahwa, anak-anak sangat senang dapat diberikan kesempatan untuk melukis jari, anak-anak merasa puas dengan karya yang telah mereka buat, walau dalam kondisi jari serta pakaian yang kotor terkena cat terlihat semangat mereka untuk mencoba melukis kembali. Tidak ada salahnya mengenalkan atau belajar Finger Painting di tempat lain tidak harus di tempat bimbingan belajar atau di sekolah, hal ini untuk melatih motorik halus anak agar lebih aktif serta produktif.

Berikut adalah hasil karya Finger Painting dari peserta didik yang mengikuti kegiatan bimbingan belajar di Rumah Pintar, berikut diantaranya sebagai berikut:

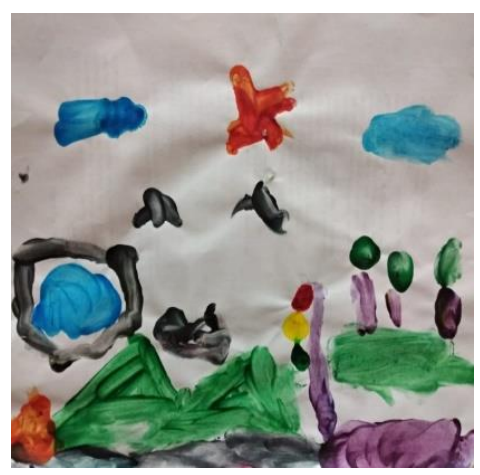

Gambar 6. Karya Siswa B 
GENERASI EMAS

Jurnal Pendidikan Islam Anak Usia Dini

Volume 1, No. 2, 2018

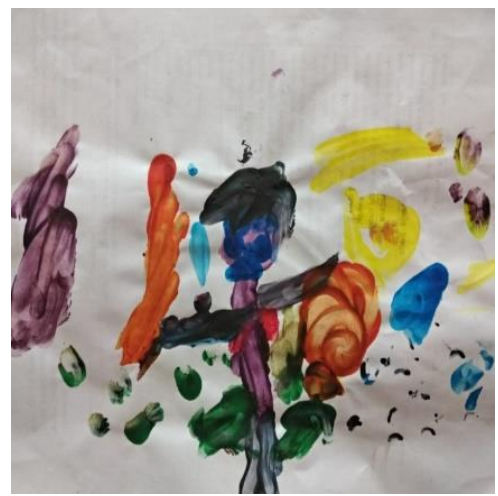

Gambar 7. Karya Siswa C

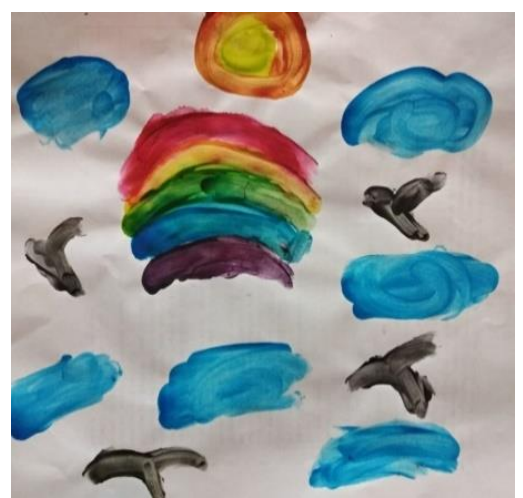

Gambar 8. Karya Siswa D

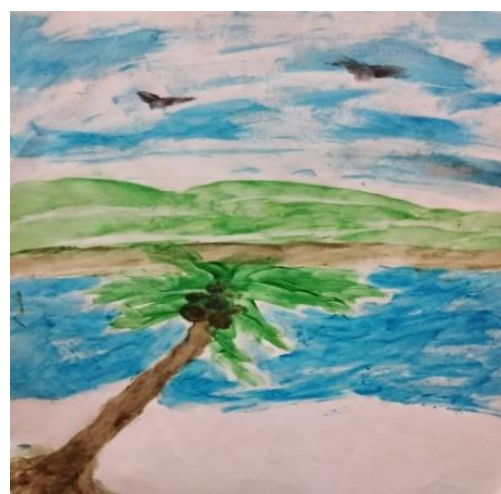

Gambar 9. Karya Siswa E

\section{KESIMPULAN}

Setelah melakukan penelitian serta hasil yang didapat, maka dapat diambil kesimpulan terkait bimbingan belajar dalam pembelajaran Finger Painting di Rumah Pintar, diantaranya sebagai berikut :

1. Bimbingan belajar yang diterapkan pada kegiatan belajar di Rumah Pintar, difokuskan pada anak usia dini dengan mengembangkan motorik halus anak

2. Anak yang mengikuti bimbingan belajar mengalami semangat yang tinggi dalam pembelajaran

3. Dengan diadakannya kegiatan Finger Painting membantu anak menjadi lebih kreatif serta produktif

4. Finger Painting memjadikan anak lebih percaya diri dan melatih motorik halus

5. Penemuan yang didapat bahwa dengan melakukan kegiatan belajar Finger Painting menggunakan teknik bermain
6. Peserta didik lebih senang berimajinasi dalam melukis

7. Anak menjadi lebih berani, tidak takut kotor dan lebih fokus

8. Mencapai keberhasilan kreativitas dalam melukis

9. Adanya pengaruh positif dari kegiatan pembelajaran melukis jari terhadap peningkatan motorik halus anak.

Melihat dari kesimpulan yang telah dipaparkan, bahwa sangatlah mudah mengajak anak usia dini untuk dibentuk. Dengan mengikuti kegiatan bimbingan belajar Finger Painting memberikan banyak manfaat untuk pertumbuhan motorik halus anak. 
GENERASI EMAS

Jurnal Pendidikan Islam Anak Usia Dini

Volume 1, No. 2, 2018

\section{DAFTAR PUSTAKA}

Dwi Kurnia, Selia. 2015. Jurnal Pendidikan Usia Dini. Volume 9 Edisi 2.

Nursisto. 1999.Kiat Menggali Kreativitas. Yogyakarta: Mitra Gama Media.

Munandar, S.C.U.1995. Pengembangan Kreativitaas Anak Berbakat. Rineka Cipta kerjasama.

Munandar, Utami S.C. 2004. Pengembangan Kreativitas Anak Berbakat. Jakarta: Rineka Cipta.
Prasetyono. 2007. Membedah Psikolog Bermain Anak. Yogyakarta: Think Jogjakarta.

Sujiono, Y.N. 2007. Konsep Dasar PAUD. Jakarta: Universitas Negeri Jakarta.

Yuda M Saputra \& Rudyanto. 2005. Pembelajaran Kooperatif Untuk Meningkatkan Keterampilan Anak TK. Jakarta: Departemen Pendidikan Nasional.

http://www.anggraenisepti.com/2018/02/ manfaat-permainan-finger-paintinguntuk.html 